\title{
TERMINATION OF POWERS OF A JUDGE OF THE CONSTITUTIONAL COURT OF UKRAINE AS A COMPONENT OF THE MECHANISM TO ENSURE ITS INDEPENDENCE
}

Gennadii O. Dubov

PhD in Law, Associate Professor of Department of Theory and History of Law and State

Taras Shevchenko National University of Kyiv

60 Volodymyrska Str., Kyiv, Ukraine, 01033

https://orcid.org/0000-0001-9042-498X

querus84@gmail.com

Bohdan O. Bondarenko

PhD researcher of Department of Constitutional Law, Faculty of Law of

Ivan Franko National University of Lviv

1 Universytetska Str., Lviv, 79000

https://orcid.org/0000-0002-9062-2684

querus84@gmail.com

Abstract. The article is devoted to the study of the grounds and procedure for termination of a judge's powers of the Constitutional Court of Ukraine as a constituent of ensuring its independence. The article aims to establish the reasons for the insufficient level of ensuring the independence of the Constitutional Court of Ukraine in terms of failure to comply with the current legislation on termination of powers of judges of the Constitutional Court and suggest recommendations to overcome defined problems. A set of methods was used for the study, such as: 1) a formal legal analysis of the texts of regulatory legal acts; 2) the historical and historical-legal analysis actualized and compared problems related to the independence of judges of the Constitutional Court during the events of 2008, 2010, 2014, and 2020-2021; 3 ) the comparative-legal method was used to compare the legal regulation of constitutional review bodies in several post-Soviet states with the transitional nature of legal and public administration systems; 4) the formal and dogmatic method allowed us to conclude the content of legal regulation for termination of powers of a judge of the Constitutional Court and changes in such regulation underwent during the existence of constitutional jurisdiction in Ukraine; 5) the systematic method defined the forms of interaction between legal institutions, in particular, the institution of removal from office in criminal proceedings and the institution of independence of judges of the Constitutional Court. As a research result, we described the key problems in the practice of termination of powers of judges of the Constitutional Court of Ukraine and suggested recommendations to solve defined problems. 
The value of this article, first of all, is due to the study of events in the Constitutional Court during 2008, 2010, 2014, and 2020-2021.

Keywords: independence, constitutional crisis, constitutional situation, constitutional jurisdiction, dismissal of a judge from office.

\section{INTRODUCTION}

The grounds and procedure for dismissal of judges of the constitutional courts from office are a separate component of constitutional and legal provision for the independence of the bodies of constitutional jurisdiction and the guarantee for the independence of judges of constitutional courts. As the procedure for appointment of judges to the constitutional courts, the procedure for termination of their powers is essential for ensuring the independence of the Constitutional Court. In fact, even perfect procedure for the appointment of judges to the constitutional courts, provided there is the possibility of arbitrary dismissal of judges from their office, cannot ensure the independence of the constitutional court.

The reason for this research was the events touching the Constitutional Court of Ukraine in 2020-2021 (Urgent Opinion of Venice Commission..., 2020). The removal of the Chairman of the Constitutional Court, the repeal of decrees on the appointment of two judges to the Constitutional Court, and other processes in Ukraine have raised the question of the insufficient level of ensuring the independence of judges of constitutional jurisdiction again. The above facts also generate a need for further thorough research in the grounds and procedure for termination of powers of judges of the Constitutional Court as a constituent of ensuring its independence.

In this context, we can mention both the reformation of the Constitutional Court due to serious social upheavals (Ukraine in 2014 and Armenia in 2015) and attempts to carry out such actions without revolutions (Ukraine in 2010). Following the events at Maidan Nezalezhnosti (Independence Square) from November 2013 to February 2014, the Verkhovna Rada dismissed 5 judges for breaking an oath (The Resolution of the Verkhovna Rada of Ukraine..., 2014). This case was extraordinary given the revolution that preceded it and the number of judges dismissed by a single resolution. However, under the Statement of the Assembly of Judges of the Constitutional Court of Ukraine on the grounds for termination of powers and dismissal from office of judges of the Constitutional Court of Ukraine for breaking an oath dated April 1, 2014 (The Statements of the Assembly of Judges, 2014), signs of oath-breaking by judges of the Constitutional Court of Ukraine were not established.

During post-revolutionary processes in Armenia, there were attempts to establish additional grounds for the dismissal from the office of judges of the Constitutional Court, which could be exercised to judges. These attempts aimed to amend the Constitution, organize a referendum on the issue, and, at the same time, adopt ordinary laws (European commission for democracy through law (Venice commission), 2019). Partially similar processes have been observed recently in Ukraine, in the form of Draft Law of Ukraine "On 
Restoring Public Confidence in Constitutional Proceedings” No. 4288 (2020) registered by the President of Ukraine.

Therefore, the purpose of this scientific research is: to study the current grounds and procedure for termination of powers of judges of the Constitutional Court of Ukraine; to establish the reasons for the insufficient level of ensuring the independence of the Constitutional Court of Ukraine in terms of failure to comply with the current legislation on termination of powers of judges of the Constitutional Court; to suggest recommendations to overcoming determined problems.

To prevent an arbitrary termination of powers of judges of the Constitutional Court, there must be the proper procedure for termination of powers. Clear and unambiguous constitutional and legislative regulation along with an appropriate level of legal and political culture and a high authority of the Constitutional Court in society (in other words, the existing constitutional democracy) will prevent politicians from exercising control over the constitutional jurisdiction and, consequently, reduce the probability of overthrowing the constitutional system in the country.

\section{MATERIALS AND METHODS}

The empirical basis of the study was a wide range of factual information that characterizes the evolution of institutional independence of the judiciary in Ukraine from the time of its establishment to the present time.

The study is based on the analysis of various regulatory legal acts (the provisions of the Constitution of Ukraine, laws, bylaws) that regulate the body of constitutional jurisdiction, their application, and amendment. We also considered law enforcement acts, including decisions of law enforcement authorities and acts adopted to implement such decisions. In addition, we considered normative material and the practice of legislative execution (in particular, criminal procedure) in aspects of its impact on the institutional independence of judges of the Constitutional Court.

The study is not limited to a formal legal analysis of the texts of regulatory legal acts, having unequal legal force, and the practice in their application. In the course of the research, factual data on the current legal regulation of the institution of independence of a judge of the Constitutional Court and its changes are introduced into a broad political and social context and investigated accordingly to the socio-political situation, occurred in relevant periods. This approach was possible due to the information we retrieved from official statements of public administration bodies, law enforcement authorities, reports of judges of the Constitutional Court of Ukraine, recognized experts, reports of authoritative mass media.

The formal and dogmatic method allowed us to conclude the content of legal regulation for termination of powers of a judge of the Constitutional Court and changes in such regulation underwent during the existence of constitutional jurisdiction in Ukraine. Having applied this method, we also highlighted the features of legal writing that have been used and may be used to improve the quality of legislation in the field of public relations.

By the historical and historical-legal analysis, we actualized and compared problems related to the independence of judges of the Constitutional Court during the events of 
$2008,2010,2014$, and 2020-2021. While conducting these analyzes, we took into account the broad socio-political context, interaction, and mutual impact of different branches of government in Ukraine when it comes to ensuring the independence of judges of the Constitutional Court.

We used the comparative-legal method to compare the legal regulation of constitutional review bodies in several post-Soviet states with the transitional nature of legal and public administration systems. This method provided for the causes and main ways of the crisis, which centered on the independence issue of judges of constitutional jurisdiction.

Following the modeling method, we predicted the impact of probable changes in the legal regulation of the independence of judges concerning the grounds for dismissal of a judge of the Constitutional Court.

The systematic method defined the forms of interaction between legal institutions, in particular, the institution of removal from office in criminal proceedings and the institution of independence of judges of the Constitutional Court.

\section{RESULTS AND DISCUSSION}

Regarding the procedure for termination of powers of judges of the Constitutional Court of Ukraine

The constitutional reform of 2016 significantly changed the procedure for termination of powers of judges of the Constitutional Court of Ukraine. Thus, under Article 149-1 of the Constitution of Ukraine, the grounds for termination of powers of judges were divided into immediate termination, fixed by the resolution of the President of the Court, and dismissal of judges. Prior to the relevant amendments to the Constitution of Ukraine, there was no such delimitation that resulted in the completely unnecessary discretion of an authorized person. The immediate termination of the powers of a judge of the Constitutional Court occurred only in the event of his or her death. In other words, the decision of the relevant authorized body was needed even in the event of the expiration of the term, for which a judge has been appointed; attaining the age of sixty-five; the entry into legal force of a verdict of guilty against a judge; the termination of citizenship of a judge. And the legal fact of dismissal of a judge of the Constitutional Court was not the event that should immediately terminate the powers of a judge, but specifically the decision of the authorized body to dismiss him. Taking into account transformational societies and unstable democracies, such discretion is too risky. There may occur situations in which the Parliament cannot receive a sufficient number of votes of people's deputies, and a judge continues to hold a position that may satisfy some political forces. Apart from the political consequences, there is another extremely negative one - the undermining of the legitimacy of the decisions adopted by the Court. Therefore, the division of grounds for immediate termination of powers and grounds for dismissal at the constitutional level is a completely logical and correct step. In particular, this stands with the recommendations of the Venice Commission (European commission for democracy through law (Venice commission), 2005).

Thus, the subjects for appointment of judges to the Constitutional Court (the Verkhovna Rada, the President, and the Congress of Judges of Ukraine) were deprived of the right to 
dismiss judges of the CCU and, accordingly, this right was granted to the Constitutional Court itself. The decision to dismiss a judge of the Constitutional Court shall be made by the Court by at least two-thirds of its constitutional judges. This significantly increased the guarantees for the independence of judges of the Constitutional Court as, previously, the authorized body could dismiss a judge for breach of the oath (that was too evaluative category to be the grounds for dismissal of a judge of the Constitutional Court).

Another important aspect of the above constitutional amendments was the distinction between the grounds for dismissal of judges of courts of general jurisdiction and judges of the Constitutional Court. According to the fifth part of Article 126 of the Constitution of Ukraine, as amended by September 30, 2016, a judge was dismissed by the body that elected or appointed him or her, in the event of:

1. the expiration of the term, for which he or she has been elected or appointed;

2. attaining by a judge the age of sixty-five;

3. inability to exercise his or her powers for health reasons;

4. violation by a judge of incompatibility requirements;

5. a breach of oath by a judge;

6. the entry into legal force of a verdict of guilty against him or her;

7. the termination of his or her citizenship;

8. declaring a judge as missing, or pronouncing him or her dead;

9. submission by a judge of a resignation or voluntary dismissal from the office.

The Venice Commission assumes that the grounds for the dismissal of judges of the Constitutional Court must be clear. For example, paragraph 21 of the Opinion on the Draft Law on amendments to the Constitution, strengthening the independence of judges (2013) states that the proposed "Article 126 concerning the dismissal of judges of the Constitutional Court, in particular the grounds for dismissal, is not very clear and causes some doubts. It is unclear whether the grounds for the dismissal of judges may also be applied to judges of the Constitutional Court or only to judges of courts of general jurisdiction. The dismissal of the Constitutional Court judges from their office should be regulated in a separate section of this court" (European commission for democracy through law (Venice commission), 2013).

As a result of the 2016 constitutional reform, such grounds for dismissal as "breach of an oath" were excluded. The Venice Commission has repeatedly pointed out that breach of an oath is very vague to be a standard for dismissing judges (European commission for democracy through law (Venice commission), 2009). In particular, this is relevant to the Judgment the European Court of Human Rights delivered in the Oleksandr Volkov v. Ukraine case (2013).

Thus, it was common for judges of the Constitutional Court to be dismissed for breaching an oath without any justification for how they breached an oath. A vivid example represents the case of V. Ivashchenko, the Judge of the Constitutional Court. Thus, by the Decree of the President of Ukraine of May 10, 2007, No. 390/2007, the judge was dismissed on the grounds of his oath-breaching. However, on June 14, 2007, the President signed Decree No. $527 / 2007$, which revoked the previous act. On the same day, by Decree of the President of Ukraine No. 529/2007, V. Ivashchenko was dismissed on the grounds of his resignation. The culmination of these decrees was the Decree of the President of Ukraine of November 
1, 2007, No. 1040/2007, which supplemented the previous grounds for dismissal with the words "due to inability to exercise his powers for health reasons." Thus, Ivashchenko was dismissed on three different grounds during 2007, which indicates only the political motives (Kyrychenko, 2017). The almost identical situation we can observe with the resignation of Pshenychnyi, the Constitutional Court judge (Decree of the President of Ukraine, 2007a; Decree of the President of Ukraine, 2007b; Decree of the President of Ukraine, 2007c).

Similar cases have happened before. For example, on May 1, 2007, S. Stanik, a retired judge of the Constitutional Court of Ukraine, was dismissed from her office by Presidential Decree No. 70370/2007 (Decree of the President of Ukraine, 2007d) on the grounds of his oathbreaching. March 25, 2008, by the Resolution of the Board of Judges of the Judicial Chamber for Administrative Cases of the Supreme Court of Ukraine (2008), Decree No. 370/2007 was finally declared illegal and repealed. The President signed Decree No. 294/2008 (2008a), which reinstated her in office, although this form of the acquisition was not provided for by law or the Constitution. The very next day, the President issued Decree No. 297/2008 (2008b), which repealed the Decree on the reinstatement of Judge Stanik to her office.

On January 27, 2010, by the Decision of the High Administrative Court of Ukraine No. K-31177/09, Decree No. 297/2008 was finally declared illegal and canceled (2010). Only on April 29, 2010 (after being reinstated as a judge of the CCU by Decree No. 585/2010 (Decree of the President of Ukraine, 2010a), she was dismissed from her office by Presidential Decree No. 587/2010 (Decree of the President of Ukraine, 2010b) due to submission of resignation. We should note that the Constitutional Court has made several decisions (Resolution No. 18/2008, 2008; Resolution No. 31/2007, 2007), by which it refused to consider such presidential decrees (on the grounds of the inconsistency of submissions and nonrelation of these decrees assessment for legality to the powers of the CCU). Unfortunately, the above positions of the Constitutional Court indicate its inability to defend itself.

On March 27, 2021, the President of Ukraine issued Decree No. 124/2021, "On Some Issues of Ensuring the National Security of Ukraine," canceling previous Decrees on the appointment of Tupytskyi and Kasminin as judges of the Constitutional Court. On April 5, 2021, the Supreme Court, composed of a judge of the Administrative Cassation Court, opened proceedings on the above Decree (Decision of the Supreme Court..., 2021) to declare it illegal and revoke it. Similar to the case with the retired judge of the Constitutional Court Stanik, the subject for the appointment dismisses, in fact, the judges of the Constitutional Court in a manner not provided by law. As the authors of the constitutional petition, which claimed this Decree as unconstitutional, rightly pointed out, decrees of the President on the appointment of CCU judges are acts of individual action and, thus, exhaust their effect by their execution, i.e., after taking by judges an oath and office (Constitutional petition of 49 people's deputies..., 2020). Also, Oleksandr Marusiak expediently notes, it absurd action to cancel the act on appointment of the person to an office because it creates legal uncertainty as only a dismissal is a legitimate antipode to appointment (Marusiak, 2021). We should emphasize that this practice has not been found exclusively in Ukraine because similar events took place in Moldova on April 24, 2021 (Velkina, 2021).

Subjects for appointment must renounce the practice of termination of powers of the CC judges, which is questionable according to the law and the Constitution. Such actions put 
direct pressure on judges of the Constitutional Court and, consequently, negatively affect its independence.

\section{Suspension of a judge of the Constitutional Court}

On December 29, 2020, by Decree No. 607/2020, the President removed Oleksandr Tupytskyi from the office of the judge of the Constitutional Court of Ukraine for two months (Decree of the President of Ukraine, 2020a). The grounds of this Decree are practically absent, except for the reference to Article 154.3 of the Criminal Procedure Code (hereinafter - CPC). The Article states that the matter of suspension from office of the persons appointed by the President of Ukraine shall be decided by the President of Ukraine on the grounds of the public prosecutor's motion under the procedure set forth by law.

Such an act of the President is clear know-how in the Constitutional Law of Ukraine, and therefore should be studied in detail.

\section{Regarding the legality of Decree No. 607/2020}

This provision of the CPC appeared in December 2016 and was never applied until December 2020. In this aspect, this Decree should be studied, first of all, for compliance with the criterion of legality.

Pursuant to Article 154.1 of the CPC, suspension from office may be applied to a person who is suspected of or charged with committing a crime. Thus, first of all, the key issue is the status of O.M. Tupytskyi in criminal proceedings under Art. 384.2, Art. 386.2 of the Criminal Code of Ukraine (perjury, artificial creation of evidence for the defense, witness tampering for refusal to testify), which is investigated by the National Bureau of Investigation. As the State Bureau of Investigation stated, 0. Tupytskyi was served with the notice of charges (The suspected judge of the Constitutional Court of Ukraine..., 2021). We should note that Tupytskyi did not come to serve the suspicion due to "family circumstances," which was later sent to him by mail (Tupytskyi did not come..., 2020). However, the potential suspect holds the opposite opinion. The only at-trial procedure can investigate the objective truth. However, concerning the topic of this research, we note that Decree No. 607/2020 was clearly illegal as, on December 29, 0. Tupytskyi did not acquire the status of a suspect in the criminal proceedings.

The second issue is the procedure for implementing this Decree.

According to the above position of the State Bureau of Investigation, "investigators of the State Bureau of Investigation, in strict compliance with the requirements of the current legislation of Ukraine, are taking comprehensive measures to ensure the implementation of the Decree." However, the nature of such measures remains in question, as neither the Decree nor the applicable legislation has a list of measures to be taken to enforce such a type of criminal proceedings as suspension from the office of a judge of the Constitutional Court.

At the moment, there is an actual question of whether O.M. Tupytskyi has admission to the building of the Constitutional Court or not. According to the position of the Administration of State Guard of Ukraine, which guards the premises of the Constitutional Court and reports to the President of Ukraine, in connection with the appeal of the State Bureau of Investigation to the Administration of State Guard of Ukraine, O.M. Tupytskyi was not allowed to enter the premises of the Constitutional Court of Ukraine. In this case, there are 
a number of questions, which are difficult to answer unambiguously due to an insufficient legal framework. For example, does the suspension of a CCU judge from the office include the need to prevent him from entering the CCU premises? Should there be a clear distinction between "workplace" and "work seat" in this case? How do these measures correlate with the internal acts of the Constitutional Court, regulating the procedure for admission to the building of the Constitutional Court? Can wages be paid? Will the absence at the work seat be considered absenteeism, which entails the corresponding negative consequences? Unfortunately, these questions do not have straight answers.

The motivation for Decree No. 607/2020 is the third issue to be examined. The generally accepted principle of law enforcement is the proper motivation of their decisions by public authorities regardless if they are the Constitutional Court, the President, or public administration bodies. As noted above, Decree No. 607/2020 does not contain such a motivation, except for the reference to the Article of CPC. This motivation is crucial to assess whether a particular type of measure is necessary to apply to ensure criminal proceedings. It allows determining risks for criminal proceedings that potential actions of the suspect may pose and restrictions that should be imposed on the person dismissed from the office. The President stated that the Decree was signed in order to "restore justice and resolve the constitutional crisis." (The President of Ukraine signed..., 2020) Given this motivation of the President, Decree No. 607/2020 was issued to continue the negative for the Constitutional Court processes, which began in November 2020 and was called the "constitutional situation," rather than to achieve the objectives of criminal proceedings. At the same time, by the above position of the State Bureau of Investigation, a suspension of a CCU judge along with his Chairman is the only possible way to prevent the latter from influencing other witnesses of these criminal proceedings - CCU officers, their resistance to provide documents at the investigator's request, interrogations, etc.

\section{On the constitutionality of Decree No. 607/2020}

The enactment of the Decree has provoked many critical assessments concerning its potential unconstitutionality. On April 8, 2021, the Constitutional Court of Ukraine received a constitutional petition from 49 people's deputies of Ukraine on the constitutionality of the Decrees of the President of Ukraine "On suspension from office of a judge of the Constitutional Court of Ukraine" dated December 29, 2020, No. 607/2020; “On suspension from office of a judge of the Constitutional Court of Ukraine" dated February 26, 2021, No. 79/2021; "On Some Issues of Ensuring the National Security of Ukraine" dated March 27, 2021, No. 124/2021 (Constitutional petition of 49 people's deputies..., 2020; Decree of the President of Ukraine, 2021a; Decree of the President of Ukraine, 2021b). Since the unconstitutionality of legal acts is established exclusively by the Constitutional Court in Ukraine, and there is no such decision at the time of writing, we will try to assess the arguments regarding the unconstitutionality of Decree No. 607/2020 below.

On December 30, 2020, a publication entitled “On the Decree of the President of Ukraine On suspension from the office of a judge of the Constitutional Court of Ukraine dated December 29, 2020, No. 607/2020" appeared on the official website of the Constitutional Court of Ukraine (Decree of the President of Ukraine, 2020a). This publication is posted on behalf of the Legal Department of the CCU and assesses the constitutionality of Decree 
No. 607/2020. Before assessing the separate arguments for their content, we should note that the publication of materials on the official website of the Constitutional Court is debatable in terms of the status of both the Constitutional Court and a separate structural unit of its Secretariat. The publication concludes the Decree "is legally invalid and cannot be executed as it is issued by the President of Ukraine, exceeding his constitutional authority, contradicts the constitutional principles for the organization of state power in Ukraine and the constitutional principles of Constitutional Court of Ukraine, encroaches on the constitutional and legal status of a judge of the Constitutional Court of Ukraine."

The Legal Department of the CCU consider this act as unconstitutional given:

1. Exhaustive nature of the constitutional powers of the President of Ukraine, which does not provide for such powers as the suspension of a judge of the Constitutional Court.

In this aspect, we should highlight that, under the Constitution, the president of Ukraine has no power to suspend a judge of the CCU. Similarly, the President has had no power to dismiss judges of the CCU from office since 2016. However, the legal position set out by the Constitutional Court in the case of Decision dated September 16, 2020, No. 11/2020 (Decision of the Constitutional Court of Ukraine, 2020) cannot be fully applied to these circumstances. The CCU actually concluded within the above Decision that the powers of the President, challenged in the course of the constitutional proceedings, are beyond his competence and should be transferred to another body (for example, the Cabinet of Ministers). In this case, the President has particular powers to appoint judges of the Constitutional Court that affect their status. Therefore, such an argument of the Legal Department of CCU cannot be independent and unappealable. In other words, if the Parliament is empowered to suspend a CCU judge from office under the procedural law, will this make the provision constitutional? The answer is probably not.

2. Impossibility to apply Article 154.3 of the CPC to judges of the Constitutional Court.

The Legal Department of the CCU believes the Constitution of Ukraine does not provide for the possibility to suspend a judge of the Constitutional Court of Ukraine from office. As for judges of courts of general jurisdiction, paragraph 6 of Chapter I of Article 131 of the Constitution of Ukraine provides for their temporary suspension to administer justice. On the contrary, the Constitution of Ukraine establishes only the grounds and procedure for dismissal of a judge of the Constitutional Court of Ukraine, termination of his or her powers, arrest or detention in custody (Articles 149, 149-1 of the Constitution of Ukraine).

The counterargument may be as follows: According to Article 24 of the Law of Ukraine On the Constitutional Court of Ukraine, a suspension of a judge of the CCU can be applied per standard procedure provided that it does not include such exceptions as detainment, detention in custody or arrest of a judge. These exceptions are applied to a CCU judge per special procedure.

If Article 154.3 of the CPC is allowed to be applied to judges of the Constitutional Court, it can be applied, by analogy, to the Prosecutor General, half of the Council of the National Bank of Ukraine, the National television and radio broadcasting Council of Ukraine. This may significantly shift the balance of checks and balances, established at the constitutional level, towards the President. 
The Constitutional Court should investigate this issue within the framework of constitutional proceedings and, accordingly, should form a legal position.

3. The ability of the President to suspend a judge of the Constitutional Court violates the unified status of the CCU judges appointed by different subjects.

The Legal Department of the CCU considers it will be a gross violation of the constitutional and legal status of all judges of the Constitutional Court of Ukraine if one of such subjects for appointment (in this case - the President of Ukraine) is granted the right to "suspend judges of the Constitutional Court of Ukraine from the office" while the other subjects (Verkhovna Rada of Ukraine and Congress of Judges of Ukraine) are not. We believe such an argument is completely self-sufficient and logical.

Oleksandr Vodiannikov expediently draws attention to another aspect, which may indicate the potential unconstitutionality of the provisions of Article 154.3 of the CPC. He believes this provision establishes a special procedure for suspension from office as a measure to ensure criminal proceedings against a separate category of officials who, according to Article 106 of the Constitution, are beyond judicial control. Thus, in the case of all other persons, the decision to suspend a person from the office is taken within the adversarial procedure by an investigating judge or a court, composed of the investigator, inquiry officer, prosecutor, and defense. However, the procedure for suspension of CCU judges is not similar, as the decision is made solely and discretionary by the President of Ukraine (Vodiannikov, 2021).

Thus, the application of such a measure to ensure criminal proceedings is extrajudicial and does not allow the defense to use the remedies and guarantees provided by the CPC.

Given the above arguments, the Decree of the President of Ukraine On suspension of a judge of the Constitutional Court of Ukraine from office dated December 29, 2020, No. 607/2020, is questionable in certain aspects of its constitutionality and, perhaps, even legality.

Until the relevant decisions are adopted within the framework of proceedings of general jurisdiction or a decision of the Constitutional Court, it shall be valid and enforceable. To rely on the first paragraph of Article 60 of the Constitution of Ukraine (No one shall be obliged to execute directions or orders that are manifestly criminal) is not relevant in this case (Decree of the President of Ukraine, 2020b). As the Decree was adopted based on the current provision of the Law, the constitutionality of which was beyond dispute, and therefore, at least given this, the category "knowingly criminal" cannot be applied to this Decree.

We support the thesis by Oksana Kuchynska that argues the necessity to harmonize the provisions of Art.149 of the Constitution of Ukraine, Art. 24 of the Law of Ukraine On the Constitutional Court of Ukraine, and Art.154.3 of the CPC (Kuchynska, 2021).

In addition, we note that a CCU judge shall not exercise the powers of the CCU Chairman in case of his suspension from the office, regardless of whether he considers himself suspended from the office of a judge of the Constitutional Court or not (Press release, 2021). This is impossible under Article 33.4 of the Law of Ukraine On the Constitutional Court of Ukraine, as only a person with the status and office of a judge of the CCU can be the Chairman of the Court. Also, the absence of the Chairman of the CCU does not "block" the work of the CCU, as according to Paragraph seven of this Article, in the absence of the Chairman of the Court, 
his duties are performed by the Deputy Chairman of the Court. If they are both absent, the oldest Judge performs their duties.

\section{Regarding the grounds for termination of powers of judges of the Constitutional Court of Ukraine}

According to Article 149.1 of the Constitution of Ukraine, the immediate grounds for termination of a judge of the Constitutional Court are:

1. expiration of his or her term of office (remain);

2. attaining the age of seventy (age limit was increased by 5 years);

3. termination of citizenship of Ukraine or acquisition of citizenship of another state (an additional basis occurred);

4. entry into force of a court decision declaring him or her missing or dead, declaring him or her incapable or partially incapable (an additional basis occurred);

5. the entry into legal force of a verdict of guilty against him or her (remain);

6. death of a judge of the Constitutional Court of Ukraine (remain).

Regarding the grounds for dismissal of a judge of the Constitutional Court of Ukraine.

1. Incapability to exercise his or her powers for health reasons.

According to paragraph 1 of Chapter one of Article 21 of the Law of Ukraine On the Constitutional Court of Ukraine, this fact must be confirmed by a medical opinion issued by a medical commission, established by the central executive body that ensures the formation and implementation of state health policy at the request of the Chairman of the Court, and, in his absence, of the Deputy Chairman of the Court, or, in the absence of both, of a judge acting as the Chairman of the Court. If this opinion is insufficient for the 12 judges of the Constitutional Court, the judge who has health problems will still be in office.

2. Violation by a judge of incompatibility requirements.

According to paragraph 1 of Chapter one of Article 21 of the Law of Ukraine On the Constitutional Court of Ukraine, the issue of violation of incompatibility requirements by a judge is considered at a special plenary session of the Court in the presence of the Standing Committee on Rules and Ethics. If the circumstances that indicate a violation of the incompatibility requirements by the judge are confirmed, the judge shall be notified about the need to eliminate such circumstances within the period established by the Court. If the judge has not remedied the breach of the incompatibility requirements within the period established by the Court, the Court shall decide on his dismissal.

However, can qualification and other requirements for a judge of the Constitutional Court be considered guarantees of his independence? To answer this question, it is necessary to clarify the legal nature of the requirement for a judge of the Constitutional Court, which applies to both candidates for a judge's office and current judges of the Constitutional Court.

At first glance, this issue is purely theoretical. However, if we turn to the recent practice of the Constitutional Court of Ukraine, in particular to Decision No. 2/2017 dated December 20, 2017 (Decision of the Constitutional Court, 2017), its applied nature becomes clear. In particular, the second part of a separate opinion of Judge Melnyk (2017) devoted to the analysis of the correlation between the qualification requirements and the essence of legal liability. Can a qualification requirement be a guarantee of independence? This question has no common answer due to a lack of a well-established understanding of the legal nature of 
the qualification requirement in the scientific doctrine and the difference in the office of judges of the Constitutional Court of Ukraine. Nevertheless, the nature of the requirement for current judges of the Constitutional Court is completely different.

M. Savenko (2001) believes the requirements to judges established by the Constitution of Ukraine and the Law of Ukraine On the Constitutional Court are aimed at ensuring the independence of judges and the Constitutional Court. P. Stetsiuk also mentions particular requirements for judges of the Constitutional Court in the context of their independence (Stetsiuk, 2013).

We assume the requirements for judges can be considered as a guarantee of their independence, as a judge of the Constitutional Court, who does not comply with these requirements, can be dismissed from the office. Article 11 of the Law of Ukraine On the Constitutional Court of Ukraine provides requirements for a judge, determining the criteria for a candidate for a judge's office and current judges of the Constitutional Court. These requirements are aimed to ensure a high professional level, high moral qualities, and independence of a judge of the Constitutional Court.

According to Art. 21 of the Law of Ukraine On the Constitutional Court of Ukraine, the grounds for dismissal of a judge is his or her violation of the requirements of Part 3, Part 4 of Art.11 of the Law. At the same time, violation of Part 2 of Art.11 (observance of standards of professional ethics) is not unconditional grounds for dismissal of a judge of the Constitutional Court. However, since the notion of substantial disciplinary misconduct is not defined in part one of Article 21 of the Law, violation of standards of professional ethics may fall under the category of substantial disciplinary misconduct and be grounds for dismissal (Law of Ukraine On the Constitutional Court of Ukraine, 2017). If a judge of the Constitutional Court does not comply with other requirements, enshrined in Art.11(1) of the Law (identical to the fourth paragraph of Article 148 of the Constitution of Ukraine), his or her powers shall be terminated (loss of citizenship, attaining the age limit, etc.). Non-compliance of a judge with the requirements of high moral qualities and recognized level of competence should fall (be a primitive cause) under the category of gross or systematic neglect of their duties. This shows the incompatibility of the status and office of a CCU judge, and therefore, is the grounds for his or her dismissal.

Thus, we can argue that the grounds for dismissal or termination of powers of a judge of the Constitutional Court are non-compliance with the requirements established for his or her office. As the grounds for dismissal of judges of the Constitutional Court guarantee their professionalism and presume that judges and their decisions cannot be misled or subject to other external influences, they are, in essence, a guarantee of their independence. Regarding the above, we can argue that the requirements for the incumbent judge of the Constitutional Court can be considered as guarantees of their independence.

In this aspect, a number of circumstances need to be investigated, such as political neutrality. Under the provisions of the Law of Ukraine On the Constitutional Court of Ukraine, Article $11(3,4)$ of this Law defines the incompatibility requirements, noncompliance with which may be grounds for dismissal. A judge of the Constitutional Court must meet the criterion of political neutrality. Namely, it is stipulated at the constitutional level that a judge of the Constitutional Court shall not participate in any political activity. 
This constitutional provision is detailed at the legislative level. Thus, under Article 11 (3) of the Law, a judge shall not belong to political parties or trade unions, show support for them publicly, and participate in any political activity. Moreover, at the time of appointment, a candidate for a judge's office shall not be a member or hold an office in a political party or other organization that has political goals or participates in political activities; be elected to an elected position in a state authority or local government body and have a representative mandate; participate in the organization and financing political agitation or other political activity.

Regarding the above, the following questions arise. Are all of the above circumstances a political activity or a public expression of commitment to a political party? If so, can these circumstances be remedied by judges themselves?

Imagine that a CCU judge funded a political party. On the one hand, the very fact of such funding can be regarded as a public expression of commitment to a particular political party, as this information is available on the official website of the National Agency Corruption Prevention. However, on the other hand, we cannot be sure that such a contribution in favor of a political party was made by him independently and not by a member of his family from the judge's account. How does such a contribution affect the authority of the Constitutional Court? Is the judge's subsequent statement that he does not support any political party sufficient to remedy such circumstances?

The Standing Committee on Rules and Ethics of the Court should investigate all these issues, together with the explanations of a judge of the Constitutional Court including but not limiting to funding a political party as an example of various incompatibility requirements). In case of similar situations, these issues should be established in the practice of the Constitutional Court. At present, the Standing Committee on Rules and Ethics of the Constitutional Court has investigated only one case of the non-compliance of a CCU judge with the requirements of political neutrality. This is a statement by Stanislav Shevchuk, a former judge of the Constitutional Court: "I will never take the oath of office if the election is rigged." (The Chairman of the Constitutional Court..., 2019). Under the Decision of the Standing Committee on Rules and Ethics of the Constitutional Court of Ukraine (Minutes of April 17, 2019) (Decision of the Standing Committee..., 2019), it was assessed as a political statement, interference in the political process, discreditation of the Chairman of the Constitutional Court, and significant damage to the authority of the Constitutional Court.

However, the Standing Committee on Rules and Ethics of the Constitutional Court of Ukraine did not examine the statement of the Ukrainian Association of International Law (Statement of the Ukrainian Association of International Law, 2019), a member of which board was Shevchuk, a former judge of the CCU. It proposed to support the candidacy of the then head of state in the next presidential election. Although, such a question was submit to be considered by the judges according to the statement of Slidenko (Interview with a Judge..., 2019), the judge of the CCU. Later, Shevchuk, the former judge of the CCU, denied his involvement in this statement (Comment of the Chairman..., 2019). We believe the Standing Committee on Rules and Ethics of the Constitutional Court of Ukraine should have investigated such circumstances to expand the practice of applying the provisions of Art. $11(3,4)$ of the Law of Ukraine On the Constitutional Court of Ukraine. 
Draft Law on the Constitutional Court of Ukraine No. 5336-1 (2016) proposed to impose restrictions on any political activity for 3 years before taking office as a judge of the Constitutional Court. However, the current law does not contain such a provision. The Venice Commission had a reservation (Draft Opinion on The Draft Law..., 2016) to such a wording as too harsh, but in our opinion, such a restriction may make sense. As the issue of potential political independence of judges of the Constitutional Court is acute in Ukraine, the establishment of such restrictions with an appropriate transition period can be supported. These restrictions do not solve all problems but complicate the choice of politically dependent candidates for the appointee.

The possibility for a judge of the Constitutional Court to carry out exclusively teaching, scientific or creative activities is another incompatibility requirement, which has a dual purpose: (1) not to distract a judge from direct duties and (2) to avoid conflicts of interest between his or her professional duties and other activities. Extrajudicial activities related to the nature of the main work are permitted (Savenko, 2001).

3. Committing significant disciplinary misconduct by a judge of the CCU, gross or systematic neglect of his or her duties, which is incompatible with the status and office of a judge of the CCU.

Under its Opinion on the proposed constitutional changes, the Venice Commission stated that it should have been clarified that only gross disciplinary misconduct [not ordinary authors] could lead to the dismissal of judges of the Constitutional Court of Ukraine. Under the revised draft amendments, the vague wording "committing acts incompatible with the status of a judge of the Constitutional Court of Ukraine" was specified by "committing a disciplinary misconduct, gross or systematic neglect of his or her duties, which is incompatible with the status and office of a judge of the CCU." (European commission for democracy through law (Venice commission), 2015). However, discussions on this provision are still ongoing. At present, only one judge has been dismissed under this circumstance.

4. The submission by a judge of a statement of resignation or of voluntary dismissal from the office.

The events surrounding the Constitutional Court in November 2020 generated many interesting questions. One of them is the possibility of dismissal of a judge of the Constitutional Court in the event of his submission of resignation or voluntary dismissal from the office. On November 3, 2020, people's deputies announced a statement calling on 11 judges of the Constitutional Court "to vacate seats of judges of the Constitutional Court of Ukraine at their own request or resign immediately." (Deputies called for the resignation..., 2020) This statement is paradoxical as the decision to dismiss a judge of the Constitutional Court is made by the Court with at least two-thirds of its constitutional membership. Thus, on the one hand, even if the judges have a desire for voluntary dismissal from the office, they cannot do this (even in the event of incapability to exercise their powers for health reasons). On the other hand, it does not allow dramatical reforming the constitutional jurisdiction body under the influence of political factors.

Another problem is that a resigned judge of the Constitutional Court may be forced to exercise his or her powers until their expiration if a majority of colleagues do not support the resignation. 


\section{CONCLUSIONS}

We can conclude that the procedure for termination of powers of a CC judge plays a crucial role in the mechanism, ensuring the independence of the constitutional court. Proper procedure and clear grounds for termination of powers of a CC judge are appropriate guarantees of independence of judges of the Constitutional Court.

Given the special competence of the constitutional jurisdiction bodies, it is important to ensure their independence from other branches of government that influence the formation of such bodies. In general, the procedure for termination of powers of a judge of a Constitutional Court should perform two functions, namely: to limit political pressure and arbitrary termination of a judge and provide the real possibility for dismissal of a judge in established cases. The existence of a procedure for terminating the powers of a judge of the constitutional court, which ensures the implementation of the above two tasks, is a necessary component of the mechanism for ensuring the independence of the constitutional court.

The constitutional reform of 2016 significantly strengthened the guarantees of independence of judges of the Constitutional Court of Ukraine, changed the procedure for their dismissal, divided and established clear grounds for termination of their powers. Some grounds for dismissal (in particular, disciplinary misconduct) need to be completed at the legislative level. Unfortunately, we are forced to state that even the absence of powers to terminate the powers of judges of the Constitutional Court does not prevent the appointing entities from doing that in a manner not provided for by the Constitution of Ukraine. Even if the possibility of arbitrary dismissal of the Constitutional Court by the President of Ukraine is allowed, it testifies to a deep crisis of constitutional culture, which cannot be resolved solely by changes to Ukrainian legislation.

\section{REFERENCES}

Comment of the Chairman of the CCU on the statement of the Ukrainian Association of International Law. (2019). Retrieved from https://www.facebook.com/ConstitutionalCourtofUkraine/photos/a.594704817596 906/785656508501735/?type=3\&theater

Constitutional petition of 49 people's deputies of Ukraine on compliance of the Constitution of Ukraine (constitutionality) to the Decree of the President of Ukraine "On suspension from office of a judge of the Constitutional Court of Ukraine" dated December 29, 2020, No. 607/2020, "On suspension from office of a judge of the Constitutional Court of Ukraine” dated February 26, 2021, No. 79/2021, "On Some Issues of Ensuring the National Security of Ukraine" dated March 27, 2021, No. 124/2021. (2021). Retrieved from https://ccu.gov.ua/sites/default/files/3_133_2021_0.pdf

Constitutional petition of 49 people's deputies of Ukraine on compliance with the Constitution of Ukraine (constitutionality) of Decrees of the President of Ukraine "On suspension from office of a judge of the Constitutional Court of Ukraine" dated December 29, 2020, No. 607/2020. (2020). Retrieved from https://ccu.gov.ua/novyna/shchodo-ukazu-prezydenta-ukrayiny-pro-vidstoronennya-vid-posady-suddikonstytuciynogo-sudu

Decision of the Constitutional Court of Ukraine. (2020). In the case on the constitutional petition of 50 people's deputies of Ukraine on the compliance of the Constitution of Ukraine (constitutionality) to particular provisions of the Law of Ukraine "On the National Anti-Corruption Bureau of Ukraine" dated September 16, 2020 No. 11/2020. Retrieved from https://zakon.rada.gov.ua/laws/show/v011p710-20\#Text

Decision of the Constitutional Court. (2017). In the case on the constitutional petition of 49 people's deputies on the compliance of the Constitution of Ukraine (constitutionality) to paragraph 7 of Chapter two of Article 42 of the Law of Ukraine On Higher Education dated December 20, 2017, No. 2/2017. Retrieved from http://www.ccu.gov.ua/sites/default/files/docs/2-p_2017.pdf 
Decision of the High Administrative Court of Ukraine No. K-31177/09 dated January 27. (2010). Retrieved from https://zakon.rada.gov.ua/laws/show/v3117760-10\#Text

Decision of the Standing Committee on Rules and Ethics of the Constitutional Court of Ukraine (2019).

Retrieved from http://www.ccu.gov.ua/sites/default/files/visnov_post_kom_0.pdf

Decision of the Supreme Court, composed of a judge of the Administrative Cassation Court Yeresko L.O.

dated April 5. (2021). Retrieved from https://reyestr.court.gov.ua/Review/96050234

Decree of the Judicial Chamber for Administrative Cases of the Supreme Court of Ukraine. (2008). Retrieved from http://www.viaduk.net/clients/vs.nsf/0/C75A418CA2DFCE30C22574570051C992?0penDocument

Decree of the President of Ukraine. (2007a). On dismissal of V. Pshenychnyi from the office of a judge of the Constitutional Court of Ukraine. Retrieved from https://zakon.rada.gov.ua/laws/show/369/2007\#Text

Decree of the President of Ukraine. (2007b). On the abolition of the Decree of the President of Ukraine dated April 30, 2007, No. 369. Retrieved from https://zakon.rada.gov.ua/laws/show/526/2007\#Text

Decree of the President of Ukraine. (2007c). On dismissal of V. Pshenychnyi from the office of a judge of the Constitutional Court of Ukraine dated June 14, 2007, No. 528/2007. Retrieved from https://zakon.rada.gov. ua/laws/show/528/2007\#Text

Decree of the President of Ukraine. (2007d). On dismissal of S. Stanik from the office of a judge of the Constitutional Court of Ukraine. Retrieved from https://zakon.rada.gov.ua/laws/show/370/2007\#Text Decree of the President of Ukraine. (2008a). On abolition of the Decree of the President of Ukraine dated March 25, 2004, No. 368. Retrieved from https://zakon.rada.gov.ua/laws/show/297/2008\#Text

Decree of the President of Ukraine. (2008b). On Question about S. Stanik. Retrieved from https://zakon. rada.gov.ua/laws/show/294/2008\#Text

Decree of the President of Ukraine. (2010a). On recognizing as invalid the Decree of the President of Ukraine dated April 3, 2008, No. 297. Retrieved from https://zakon.rada.gov.ua/laws/show/587/2010\#Text Decree of the President of Ukraine. (2010b). On dismissal of S. Stanik from the office of a judge of the Constitutional Court of Ukraine. Retrieved from https://zakon.rada.gov.ua/laws/show/587/2010\#Text

Decree of the President of Ukraine. (2020a). "On suspension from office of a judge of the Constitutional Court of Ukraine” dated December 29, 2020 No. 607/2020. Retrieved from http://www.ccu.gov.ua/novyna/ shchodo-ukazu-prezydenta-ukrayiny-pro-vidstoronennya-vid-posady-suddi-konstytuciynogo-sudu

Decree of the President of Ukraine. (2020b). No. 607/2020 dated December 29, 2020. Retrieved from https://www.president.gov.ua/documents/6072020-36197

Decree of the President of Ukraine. (2021a). "On suspension from office of a judge of the Constitutional Court of Ukraine” dated February 26, 2021, No. 79/2021. Retrieved from https://zakon.rada.gov.ua/laws/ show/79/2021\#Text

Decree of the President of Ukraine. (2021b). "On Some Issues of Ensuring the National Security of Ukraine" dated March 27, 2021, No. 124/2021. Retrieved from https://www.president.gov.ua/ documents/1242021-37701

Deputies called for the resignation of judges of the CCU who supported the decision on e-declarations. (2020). Retrieved from https://www.ukrinform.ua/rubric-polytics/3128893-deputati-zaklikali-piti-uvidstavku-suddiv-ksu-aki-pidtrimali-risenna-pro-edeklaracii.html

Draft Law "On Restoring Public Confidence in Constitutional Proceedings" No. 4288. (2020). Retrieved from https://w1.c1.rada.gov.ua/pls/zweb2/webproc4_1?pf3511=70282

Draft Law on the Constitutional Court of Ukraine No. 5336-1. (2016). Retrieved from http://w1.c1.rada. gov.ua/pls/zweb2/webproc4_1?pf3511=60542

Draft Opinion on The Draft Law on The Constitutional Court No. 870/2016. (2016). Retrieved from https://www.venice.coe.int/webforms/documents/?pdf=CDL(2016)042-e

European commission for democracy through law (Venice commission). (2019). Armenia - Joint opinion of the Venice Commission and the Directorate of Human Rights (DHR) of the Directorate General of Human Rights, and rule of law (DGI) of the Council of Europe, on the amendments to the Judicial Code and some other laws, adopted at its 120th Plenary Session, Venice, 11-12 October 2019. Retrieved from https://www. venice.coe.int/webforms/documents/?pdf=CDL-AD(2019)024-e

European commission for democracy through law (Venice commission). (2005). Opinion on the amendments to the constitution of Ukraine adopted on 8.12.2004 Adopted by the Commission at its 63rd plenary session (Venice, 10-11 June 2005). Retrieved from http://www.venice.coe.int/webforms/ documents $/$ ?pdf=CDL-AD(2005)015-e

European commission for democracy through law (Venice commission). (2013). Draft Opinion on the Draft Law on amendments to the Constitution, strengthening the independence of judges (including an explanatory note and comparative table) and Changes to the Constitution of Ukraine proposed by the 
Constitutional Assembly of Ukraine. Retrieved from https://www.venice.coe.int/webforms/documents/ default.aspx?pdffile=CDL(2013)025-e

European commission for democracy through law (Venice commission). (2009). Opinion on the Draft Law of Ukraine Amending the Constitution presented by the President of Ukraine, adopted by the Venice Commission at its 79th Plenary Session (Venice, 12-13 June 2009). Retrieved from https://www.venice.coe. int/webforms/documents/default.aspx?pdffile=CDL-AD(2009)024

European commission for democracy through law (Venice commission). (2010). Joint Opinion on the Law Amending Certain Legislative Acts of Ukraine in relation to the Prevention of Abuse of the Right to Appeal by the Venice Commission, the Directorate of Co-operation within the Directorate General of Human Rights and Legal Affairs of the Council of Europe, adopted by the Venice Commission at its 84th Plenary Session (Venice, 15-16 October 2010). Retrieved from https://www.venice.coe.int/webforms/documents/default. aspx?pdffile=CDL-AD(2010)029-e

European commission for democracy through law (Venice commission). (2015). Opinion on the Amendments to the Constitution of Ukraine Regarding the Judiciary Endorsed by the Venice Commission 2324 October 2015, No. 803/2015 CDL-AD (2015) 027. Retrieved from https://www.venice.coe.int/webforms/ documents/default.aspx?pdffile=CDL-AD(2015)027-e

Interview with a Judge of CCU Ihor Slidenko. (2019). Retrieved from https://ccu.gov.ua/publikaciya/ intervyu-suddi-ksu-igorya-slidenka-shchotyzhnevyku-dzerkalo-tyzhnya-23032019

Kuchynska, O. (2021). On the issue of temporary suspension of a judge of the Constitutional Court from the office based on Art.154.3 of the CPC. Retrieved from https://zib.com.ua/ua/146297-schodo_pitannya timchasovogo_vidstoronennya_vid_posadi_suddi.html

Kyrychenko, Yu. (2017). Paralyzed guard: how to make the Constitutional Court of Ukraine truly independent. Retrieved from http://pravo.org.ua/img/zstored/files/1(3)(1).pdf

Law of Ukraine On the Constitutional Court of Ukraine. (2017). Article 21. Dismissal of a judge of the Constitutional Court. Retrieved from https://zakon.rada.gov.ua/laws/show/2136-19\#Text

Marusiak, O. (2021). Can the President of Ukraine cancel decrees on the appointment of judges to the Constitutional Court? Retrieved from https://blog.liga.net/user/amarusiak/article/39497

Melnyk, M.I. (2017). A separate opinion of the judge of the Constitutional Court M.I. Melnyk on the Decision of the Constitutional Court in the case on the constitutional petition of 49 people's deputies on the compliance of the Constitution of Ukraine (constitutionality) to paragraph 7 of Chapter two of Article 42 of the Law of Ukraine On Higher Education dated December 20, 2017, No. 2/2017. Retrieved from http://www. ccu.gov.ua/sites/default/files/docs/melnyk.pdf

Oleksandr Volkov v. Ukraine case of 09 January 2013, Application No. 21722/11. (2013). Retrieved from https://hudoc.echr.coe.int/eng\#\{\%22itemid\%22:[\%22001-126884\%22]\}

Press release. (2021). Retrieved from https://ccu.gov.ua/novyna/povidomlennya-dlya-zmi-4

Resolution No. 18/2008 on refusal to open constitutional proceedings in the case on the constitutional petition of 56 people's deputies of Ukraine on compliance of the Constitution of Ukraine (constitutionality) to the Decree of the President of Ukraine "On abolition of the Decree of the President of Ukraine of March 25, 2004, No. 368” dated June 19. (2008). Retrieved from http://ccu.gov.ua/sites/default/files/ndf/18-u/2008. doc

Resolution No. 31/2007 on refusal to open constitutional proceedings in the case on the constitutional petition of 56 people's deputies of Ukraine on compliance of the Constitution of Ukraine (constitutionality) to the Decree of the President of Ukraine "On dismissal of S. Stanik from the office of judge of the Constitutional Court of Ukraine” of June 19. (2007). Retrieved from http://ccu.gov.ua/sites/default/files/ ndf/31-u/2007.doc

Savenko, M. (2001). Independence of a judge of the Constitutional Court of Ukraine. Bulletin of the Constitutional Court of Ukraine, 1, 75-84.

Savenko, M. (2001). Independence of a Judge of the Constitutional Court of Ukraine. Bulletin of the Constitutional Court of Ukraine, 1, 75-84.

Statement of the Ukrainian Association of International Law. (2019). Retrieved from https://www.uail. com.ua/wp-content/uploads/2019/03/UAMP_zayava_19.03.19.pdf

Stetsiuk, P. (2013). Guarantees for independence of the Constitutional Court of Ukraine. Bulletin of the Constitutional Court of Ukraine, 1, 63-71.

The Chairman of the Constitutional Court, Stanislav Shevchuk, has stated that he will refuse to take the oath of office if the election is rigged. (2019). Retrieved from https://strana.ua/news/192626-ja-nikohdane-privedu-k-prisjahe-prezidenta-esli-vybory-budut-sfalsifitsirovany-hlava-ks.html 
The President of Ukraine signed a decree dismissing Oleksandr Tupytskyi from the office of a judge of the Constitutional Court for a period of two months. (2020). Retrieved from https://www.president.gov.ua/ news/prezident-ukrayini-pidpisav-ukaz-pro-vidstoronennya-oleksand-65857

The Resolution of the Verkhovna Rada of Ukraine "On Reaction to the Fact of Breaking an Oath of a Judge by Judges of the Constitutional Court of Ukraine" dated February 24 (2014). Retrieved from https://zakon. rada.gov.ua/laws/show/775-18\#Text

The Statements of the Assembly of Judges. (2014). Retrieved from https://ccu.gov.ua/novyna/rishennyazboriv-suddiv-ta-vysnovok-postiynoyi-komisiyi-z-pytan-reglamentu-ta-etyky

The suspected judge of the Constitutional Court of Ukraine and its Chairman violates the norms of the CPC of Ukraine (Updated). (2021). Retrieved from https://dbr.gov.ua/news/dbr-povidomilo-pro-pidozru-suddikonstitucijnogo-sudu-ukraini-ta-jogo-golovi

Tupytskyi did not come to the Prosecutor General's Office, but the notice of suspicion was sent to him by mail - a spokeswoman (Updated). (2020). Retrieved from https://www.radiosvoboda.org/a/newskonstytucijny-sud/31022530.html

Urgent Opinion of Venice Commission on the Reform of the Constitutional Court of Ukraine. (2020). Retrieved from https://www.venice.coe.int/webforms/documents/default.aspx?pdffile=CDL-PI(2020)019-e

Venkina, E. (2021). The EU demanded that the Moldovan Parliament respect the decisions of the Constitutional Court. Retrieved from https://www.dw.com/ru/es-potreboval-ot-parlamenta-moldovyuvazhat-reshenija-konstitucionnogo-suda/a-57321985

Vodiannikov, O. (2021). Royal croquet or how to suspend a judge of the Constitutional Court of Ukraine from the office. Retrieved from https://lb.ua/blog/oleksandr_vodennikov/476220_korolivskiy_kroket_abo_ yak.html 